\section{引用 文 献}

1) 牧野富太郎：新植物図鑑北隆館 (1963).
2) 行方沼東 : シダの採集と培美 (総頁数 357), 加島書店 (1963).

3）川島良一・好山宣重：A T A 飞上る烟地の多管生雑草防除. 雑 草研究 2, (1963).

\title{
Ecology and Chemical Control of Field Horsetail (Equisetum arvense L.)
}

Nobuo Nihei, Tohru Sasaki and Shin-ichi Yamazaki

Furukawa Branch Station, Miyagi Prefectural Agricultural Experiment Station, Furukawa, Miyagi

\section{Summary}

Auto-ecology of field horsetail was surveyed from the standpoints of emergence from spore, elongation of subterranean stem, emergence of root from vegetative stem, depth of emergence, effect of soil $\mathrm{pH}$, effect of fertilization and so on.

For the purpose of the control of this weed in barley or wheat fields, the application of linuron and $2,4-\mathrm{D}(100 \mathrm{~g}+200 \mathrm{~g}$ in a. i. per $10 \mathrm{are})$ at the times between vigorous emegence stage of this weed and 15 days before the harvest would bring a good result. When next crop cultivation will be expected, the former application time should be selected.

\section{ヨモギの生理生態およびその防除法に関する研究}

\section{第 2 報 種子繁殖について}

\author{
九州大学農学部作物学教室 伊藤健次 - 井手欽也 - 开之上準
}

\section{1.は じめに}

ヨモギが種子より発芽し生長しても，その個体から地 下茥の発生がなければそれ 1 個体で一生を終つてしまう ことになり，実生のヨモギは 1 年生雑草としての重要性 しかもたないであろう。しかし実生個体も地下茎を発生 するとすれば，しない場合にくらべて，その雑草として の害は著しく大きなものとなることは明らかである。

そこでこの点を確かめるために，種子による繁殖につ いての実験をするに先立ち, 次のような処理を試みた。

ファイトトロンの $20^{\circ} \mathrm{C}-15^{\circ} \mathrm{C}$ でヨモギの実生個体を 育て, 播種 60 日後 (葉数 17 枚, 草丈 $15 \mathrm{~cm}$ ), 苗の茎 基部に子葉節より $1 \mathrm{~cm}$ 上まで培土した。処理 10 日後 に茎の基部より培土を除去し観察したところ, 茎基部の 腋芽が培土後地下茥となつて伸長し, 最大 $5 \mathrm{~cm}$ に達し ていた（第 1 図）。一方無処理区の個体では，茎基部の 腋芽が分枝としてわずかに $4 \sim 5 \mathrm{~mm}$ ぐらい伸びている 程度であつた（第 2 図）。

このよらにヨモギの実生個体が地下茎を発生するとい ら事実は，1年間にヨモギ種子 1 粒から数個体ないし数
十個体のヨモギが育つことを意味し，またヨモギ個体は 主に地下茥で越冬することを考えると，1年生から多年 生雑草になることをも意味する。自然条件下ではヨモギ の実生傴体の茎基部が土中に埋まることは当然起こりう ると考えられるところから，ヨモギの繁殖においては種 子による繁殖様式もかなり重視する必要があるのではな いかと考えられる。以下ヨモギの開花結実および種子の 発芽などについて行なつた実験結果について報告する。

\section{2. 実験および調査とその結果}

\section{(1) 開花と稔実}

\section{1）ヨモギの開花と日長}

材料には草丈 $10 \mathrm{~cm}$, 葉数 8〜10 枚の実生個体および 地下茎の先端が伸長して地上に出芽し同じぐらいの大き さにまで生長した個体を用いて，7月 12 日より短日処 理 (8 時間日長) と 長日処理 (補光 - 昼光色螢光灯 $10 \mathrm{~W}$ 1 個，植物体より $1 \mathrm{~m}$ 上方）を行なつた。

その結果, 短日区は実生個体抽よび地下茎からの個体 ともに, 処理開始 24 日後に最初の花蕾が出現し, 40 日 後には花粉がとび始めた。なおこれら短日区の個体の草 


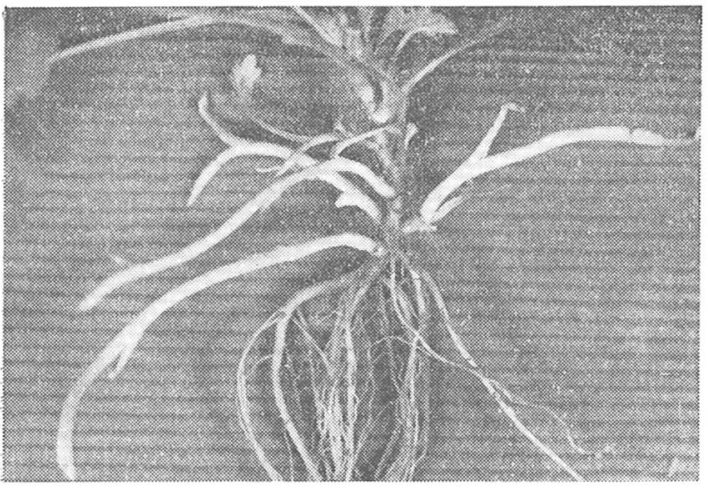

第 1 図 播種後 60 日苗の基部に培土後 10 日目 腋芽の新地下茎への変化功みられる。

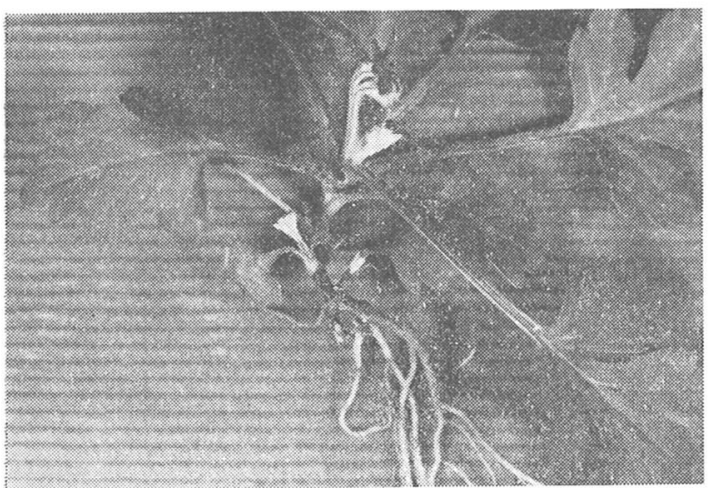

第 2 図第 1 図の対照区

腋芽がみられる。

丈は約 $70 \mathrm{~cm}$ であつた（第 3 図）。

一方, 長日区の個体は短日区の個体上り草丈漓く最 高 $120 \mathrm{~cm}$ になで生長していたが花蕾はみられず，その 後約 20 日間長日処理を続けたがやはり花蕾はみられな かつた。な抢短日区の個体の頭花搂は自然日長下の個体 より少なく，また稔実率も極めて低いようであつた。

\section{2) 開花順序}

さてヨモギは短日植物であることがわかつたが，次に 围場に播種し 5 月 24 日に発芽した実生個体の開花順序 について調べた。なおここで開花とは，葯が裂開して花 粉がとび始めることを指す。この俔体の開花始は 10 月 1 日，終了は 10 月 6 日，草丈は約 $1 \mathrm{~m}$ であつた。

その結果, (1) まずはじ为纪主茎の中央部の第 1 次分 枝の中央部掠よび基部の第 2 次分枝上の頭花が開花し， (2) その後主茎の中央部の第 1 次分枝の先端部，下部の 1 次分枝の基部㧍よび上部の 1 次分枝の基部㧍よび中央 部の頭花が開花し，(3) 更に主茎の下部 1 次分枝の先端 および上部 1 次分枝の先端が開花し，(1) 最後に主茎の 最先端部の頭花が開花して全体の開花を終了した。なお

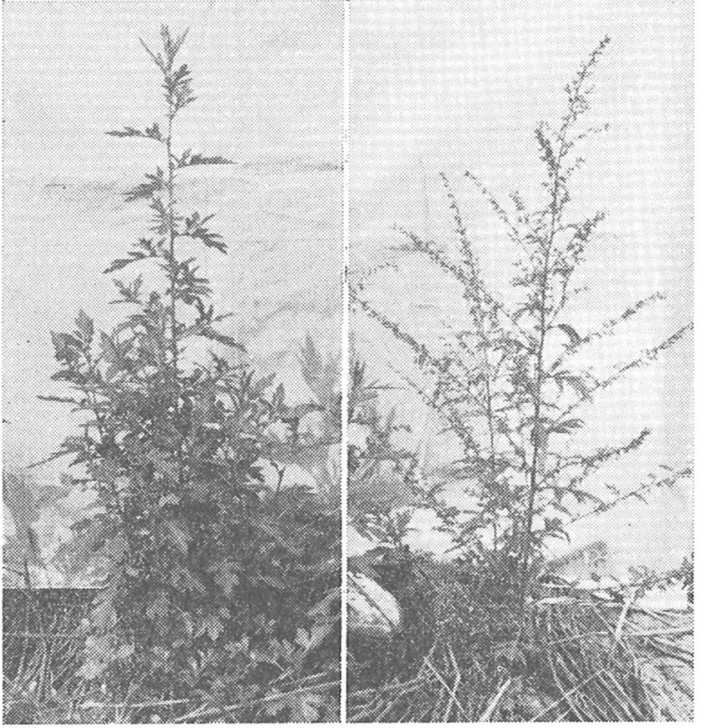

第3 図ヨモギの開花と日長処理 左: 艮日区, 右 : 短日区

1 㧣全体が開花を終了するのに約 6 日を要した。

\section{3） 1 株の頭花数㧍よび 1 頭花内の小花数}

ヒメムカショモギでは 1 株に約 80 万粒の種子が生産 される と報告されている。ヨモギは 1 頭花内に十数個 の小花を有し，その小花に各々 1 個の種子を生ずるの で，頭花が多ければ多いほどたくさんの種子ができるこ とになる。そこで 1 株当りの頭花数を調査した。材料に は各種草丈のものを集め, 全頭花数を調べ, 次の結果を 得た (第 1 表)。

第 1 表 1 株当り頭花数

\begin{tabular}{r|c|c|c}
\hline \hline 株 No. & 草 & 大 $(\mathrm{cm})$ & 頭 花 数 (花) \\
\hline$(1)$ & 紫强色花 & 185.0 & 11,865 \\
$(2)$ & 143.0 & 14,217 \\
$(3)$ & 135.0 & 3,182 \\
$(4)$ & 70.0 & 2,149 \\
\hline
\end{tabular}

第1表より明らかなように，大型（草丈 $185 \mathrm{~cm}$ ）の もので約 1 万 4 千個，小型 (草丈 $70 \mathrm{~cm}$ ) のもので約 2 千個であり，平均して 1 株当り 7 千 8 千個の頭花をつ けるものと推定される。

さてヨモギ 1 株の頭花数はその株の草丈に比例し，子 つら草丈 $100 \mathrm{~cm}$ 前後のもので 7 千 8千個の頭花をつ けることがわかつた。ところでヨモギ属の 1 頭花内には 舌状花と筒状花（雨者をあわせて小花と呼ぶ）があるこ とが知られているので, 次に 1 頭花内の小花数について 調査した。な㧍調查には屋外に生えている個体や固場に 植えた奏生個体を用いた。その結果を第 2 表に示す。 
第 2 症 ヨモギの 1 頭花内の舌状花と䇠状花

\begin{tabular}{|c|c|c|c|c|c|c|}
\hline \multirow{2}{*}{ 株 } & \multirow{2}{*}{ No. } & 小 & 花 & 数 & （花） & \\
\hline & & 舌状花 & \multicolumn{2}{|c|}{ 筒状 花 } & 合 & 計 \\
\hline (1) & 紫褐色花 & 6.0 & & 7.0 & & .0 \\
\hline (2) & I" & 6.6 & & 7.6 & & 2 \\
\hline (3) & " & 7.6 & & 9.9 & & .5 \\
\hline (4) & 黄 色 花 & 6.3 & & 11.2 & & .5 \\
\hline
\end{tabular}

第 2 表より，ヨモギの 1 頭花内にはほぼ 15 17 個の 小花が含まれており, 舌状花と筒状花の割合は $4: 6$ な いし $5: 5$ であつた。これらの1頭花内における配置は キク科の他の植物と同じく5), 両性花の筒状花は頭花の 中央部に集まつており，雌性のみから成る舌状花はその 周辺に並んでいる。なお 1 頭花内にある 15 17 個の小 花が全部稔実するとすれば，草丈 $180 \mathrm{~cm}$ ぐらいの株で 20 万粒， $70 \mathrm{~cm}$ ぐらいの株では約 3 万粒の種子を産する ことになり，ヒメムカショモギより少ない。

\section{4）自然条件下における出蕾期および開花期}

調査によれば，北部九州におけるヨモギの出蕾期は 8 月下旬 9 月上旬で, その後受精までは更に 1 力月を要 するようである。1頭花内においては, 舌状花の出現は 筒状花の花粉飛散開始より $2 \sim 3$ 日早く, また株当り花 粉飛散期間は 10 日内外であつた。

なお 1 頭花における筒状花についてその花粉飛散日数 を調査した結果 (第 3 表), 筒状花の花粉飛散は周辺部

第 3 表 1 頭花内の筒状花の 1 日当り開花数（花）

\begin{tabular}{lc|c|c|c|c|c|c|c|c}
\hline \multirow{2}{*}{ 株 No. } & \multicolumn{7}{|c}{ 開花始まりからの経過日数 (日) } \\
\cline { 3 - 10 } & 1 & 2 & 3 & 4 & 5 & 6 & 7 & 平均 \\
\hline (1) & 紫褐色花 & 2.6 & 1.9 & 0.7 & 1.0 & 1.0 & 0.4 & 0.3 & 1.2 \\
(2) & $\prime \prime$ & 2.4 & 1.8 & 1.2 & 1.6 & 1.5 & 0.7 & 0.3 & 1.4 \\
(3) & $\prime \prime$ & 2.4 & 1.8 & 1.4 & 2.4 & 1.5 & 1.1 & - & 1.8 \\
$(4)$ & $\prime \prime$ & 3.2 & 1.5 & 2.0 & 2.1 & 0.8 & - & - & 1.9 \\
(5) & $\prime \prime$ & 2.4 & 2.6 & 1.4 & 2.0 & 0.7 & - & - & 1.8 \\
(6) & $\prime \prime$ & 1.8 & - & 1.5 & 1.7 & 1.4 & 1.2 & 0.7 & 1.2 \\
平 & 均 & 2.5 & 1.9 & 1.4 & 1.8 & 1.2 & 0.9 & 0.4 & 1.55 \\
\hline
\end{tabular}

から中央部に進み 1 日平均 1.5 花で，1頭花内の筒状花 の花粉飛散は約 6 日で終了する。そのうち最初の 2 3 日間に開花する数がやや多いよらである。

\section{5）受粉および稔実率}

今までの調查結果から，ヨモギ株においては，それぞ れの小花が全部稔実したとすれば 3 万〜 20 万糔という 莫大な種子が生産されると推察される。そこで野外に生 えている株および圃場で実生を育てた株など，いろいろ のタイプのヨモギについて稔実率を調査した。調查は株 内の 1 次分枝を株の上, 中, 下の 3 部分に分け, 更に各 部の 1 次分枝より出ている 2 次分枝を先端, 中央, 基部 に分け，各部位 10 花ずつをとり，その稔実率を調べた。
その際舌状花および筒状花の花数についても調查した。 その結果学第 4 表に示す。

第 4 表 1 株内上中下枝の小花数と稔実率

\begin{tabular}{|c|c|c|c|c|c|c|c|c|c|c|c|}
\hline \multirow{2}{*}{ 跣 } & \multirow{2}{*}{ No. } & \multirow{2}{*}{$\begin{array}{l}\text { 分 } \\
\text { 枝 }\end{array}$} & \multirow{2}{*}{$\begin{array}{l}\text { 部 } \\
\text { 位 }\end{array}$} & \multicolumn{2}{|c|}{ 小 花 } & \multirow{2}{*}{$\frac{\text { 数 }}{\text { 計 }}$} & \multicolumn{3}{|c|}{ 稔 実 粒 数 } & \multicolumn{2}{|c|}{ 稔実率（\%） } \\
\hline & & & & \begin{tabular}{|l|} 
舌状| \\
花|
\end{tabular} & 䉍状 & & 姬状伤 & 筒状 & 計 & 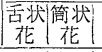 & 計 \\
\hline \multirow{10}{*}{ (1) } & \multirow[b]{3}{*}{ 紫 } & & 先 & 6.0 & 7.2 & 13.2 & 2.7 & 1.8 & 4.5 & $|45.0| 25.0 \mid$ & 34.1 \\
\hline & & & 中 & 6.0 & 7.2 & 13.2 & 2.6 & 1.2 & 3.8 & $43.3 \mid 16.6$ & 30. \\
\hline & & & 基 & 6.1 & 7.0 & 13.3 & 2.3 & 1.0 & 3.3 & $37.7 \mid 13.9$ & 24.8 \\
\hline & & \multirow{3}{*}{ 中 } & 先 & 6.0 & 6.9 & 12.9 & 2.3 & 1.0 & 3.3 & 38.314 .5 & 25.5 \\
\hline & & & 中 & 6.0 & 7.2 & 13. 2 & 2.2 & 1.4 & 3.6 & 36.619 .4 & 27.2 \\
\hline & & & 基 & 6.0 & 6.7 & 12.7 & 2.4 & 1.1 & 3.5 & $40.0 \mid 16.4$ & 27.6 \\
\hline & \multirow{4}{*}{ 花 } & \multirow{3}{*}{ 下 } & 先 & 6.1 & 7.1 & 13.2 & 4. 1 & 1.7 & 5.8 & 67.225 .7 & 44.0 \\
\hline & & & 中 & 6.2 & 6.9 & 13.1 & 1.8 & 1.5 & 3.3 & $|29.021 .7|$ & 25.2 \\
\hline & & & 基 & 6.0 & 6.6 & 12. 6 & 1.6 & 1.3 & 2.9 & \begin{tabular}{|l|l|}
26.7 & 19.7 \\
\end{tabular} & 23.0 \\
\hline & & & 6.0 & 7.0 & 13.0 & 2.4 & 1.3 & 3.7 & $|40.0| 18.6 \mid$ & 28.4 \\
\hline
\end{tabular}

\begin{tabular}{l|l|l|l|l|l|l|l|l|l|l}
\hline (2) 紫褐 & 全平均 & 6.6 & 7.6 & 14.2 & 3.7 & 2.2 & 5.9 & 56.1 & 28.9 & 41.5 \\
\hline
\end{tabular}

\begin{tabular}{ll|l|l|l|l|l|l|l|l} 
(3) $/ 7.6$ & 7.6 & 9.9 & 17.5 & 0.4 & - & 0.4 & 5.0 & - & 2.3
\end{tabular}

\begin{tabular}{l|l|l|l|l|l|l|l|l|l|l} 
(4) 黄 & " & 6.3 & 11.2 & 17.5 & 0.1 & 0.4 & 0.5 & 1.6 & 3.7 & 2.9 \\
\hline
\end{tabular}

注) 各数值は 10 花平均の值を示す。

第 4 表より明らかなよらに，株全体の稔実率が高いも のでも低いものでも，株の分枝の位置のちがいにより稔 実率に大きな差はなかつた。この調查の範囲では稔実 率は最も高い株で約 $40 \%$, 最も低い株で約 $2 \%$ と, 株の らがいによつてかなり差がみられたが，平均するとヨモ ギの稔実率は約 $20 \%$ 程度ではないかと推定される。な 小稔実率が $20 \%$ とすれば，ヨモギ 1 株の産する種子量 は, 草丈 $180 \mathrm{~cm}$ ぐらいのもので約 4 万粒, $70 \mathrm{~cm}$ ぐら いのもので約 5 千粒となり, ヒメムカショモギで報告さ れている量よりはかなり少ないことになる。

\section{（2）種子の発芽能力}

種子の発芽を考える場合, 開花後発芽能力を有するま 第 5 表 開花後日数と発芽能力 $\left(25^{\circ} \mathrm{C}\right)$

\begin{tabular}{|c|c|c|c|c|c|c|c|c|c|c|c|c|c|}
\hline \multirow{3}{*}{ 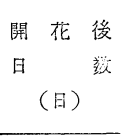 } & \multicolumn{5}{|c|}{ 発 } & \multicolumn{3}{|c|}{ 芽 } & \multicolumn{5}{|c|}{ 率 （\%) } \\
\hline & & & 㯺 & & 床 & 㣪 & & 日 & 数 & & (日) & & \\
\hline & 1 & 2 & 3 & 4 & 5 & 6 & 7 & 8 & 9 & 10 & 11 & 12 & 13 \\
\hline 10 & & & & & & & & & & & & & - \\
\hline 20 & & & & - & 1 & 4 & 7 & 11 & 13 & 14 & & & \\
\hline 30 & & - & 4 & 5 & 8 & & & & & & & & \\
\hline 40 & - & 11 & 26 & 48 & 63 & 66 & 58 & & & & & & \\
\hline 50 & - & 2 & 31 & 47 & 65 & 68 & 69 & & & & & & \\
\hline 60 & - & 8 & 36 & 47 & 55 & 59 & 61 & & & & & & \\
\hline 70 & - & 7 & 33 & 43 & 53 & 57 & & & & & & & \\
\hline 80 & - & 10 & 47 & 55 & 68 & 69 & 71 & & & & & & \\
\hline 90 & - & 9 & 52 & 65 & 70 & 72 & 72 & 73 & & & & & \\
\hline 昨年率種子 & - & 4 & 5 & 5 & 27 & 42 & 49 & 51 & 54 & 54 & 54 & 57 & \\
\hline $\begin{array}{l}\text { 注 1) 調 } \\
\\
\text { 2) 採 }\end{array}$ & & $\begin{array}{l}: 10 \\
\text { 花種 } \\
\text { 開花: }\end{array}$ & & & & 日) & & & & & & & \\
\hline
\end{tabular}


でに必要な曰数, および休眠の有無などは重要な問題で ある。この点について次のような実験を行なつた。調查 には 5 月 24 日に発芽し, 開花期間が 10 月 1 日 9 日で 草丈約 $130 \mathrm{~cm}$ の実生個体を用い, 受粉後 10 日招きに 採種して直ちに $25^{\circ} \mathrm{C}$ の定温器内で発芽試験を行なつた。 発芽試験は 1 区 50 粒の 2 区制とした。その結果を第 5 表に示す。

第 5 表より明らかなように，開花終了後 10 日目の種 子は全く発芽しなかつたが，20日目の種子は約 15\%が 発芽した。ところが 50 日目の種子は約 $70 \%$ が発芽し た。なおこの值は, この株から得られた成熟種子の発芽 率とほぼ同じであつた。また開花終了後約 70 日経過す ると落果が始まるが，これは北部九州では 12 月上旬頃 である。落果始は株によつてまちまちで, 落果期間は長 く，少しずつ落果して，翌年 1 月 1 杯でまだ落果を終了 しない株もあつた。以上の結果より考えると，ヨモギ種 子にはほとんど休眠はないようである。

種子の大きさ抢よび形は, 舌状花にできる種子と筒状 花にできる種子とでは少し異なり(第 4 図), 舌状花に
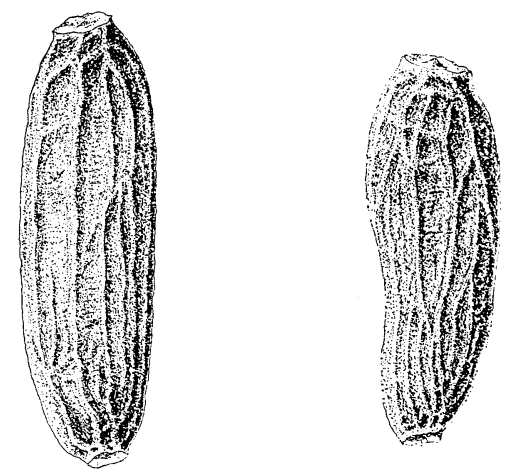

第 4 図 ヨモギ種子の外部形態 左: 舌状花種子, 右 $:$ 筒状花種子

できる種子は細長く(約 $1.5 \mathrm{~mm}$ ) 花弁の附着部分がせま く, 筒状花の種子はそれよりやや短かく(約 $1.4 \mathrm{~mm}$ ) 花 弁の附着部分が少し広い。

このようにヨモギの種子は非常に小さく, 千粒重はわ

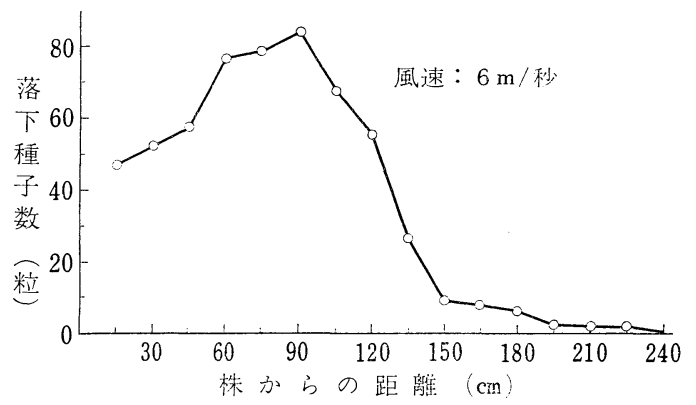

第 5 図 風の強さと種子の飛散
ずか $110 \mathrm{mg}$ 程度であるから, 自然条件下に晾いて風に よる飛散も大きいのではないかと考えられる。そこで種 子が自然落下を開始しはじめたポット植えの株を扇風機 の直前に圆き, 風速 $6 \mathrm{~m} /$ 秒 (株の直前の測定值) の風 を株にあて，㣫子の飛散距離を調べた（第 5 図）。その 結果, この程度の風速では落下種子の $80 \%$ 以上が株か ら $1 \mathrm{~m}$ 以内に落下したが，2 $\mathrm{m}$ 以上とぶ稔実種子もみら れた。この結果から推测すれば, 自然条件下では種子は かなり遠距離までとぶであろらと考えられる。

\section{（3）環境条件と種子発茅}

1）種子および実生苗の越冬

自然条件下に打けるヨモギの種子による繁殖を考える 場合, この植物が短日植物であり種子が稔実するのが 11 月下旬であることから, 種子が植物体上で頭花内に 入つたまま越冬するのか, 地上洛下して種子で越冬す るのか, あるいはま発芽して実生苗として越冬するの かが問題となる。そこで自然条件下における観察ととも に，次のような実験を行なつた。受精後 70 日目の完熟 種子を 30 粒ずつ極薄の綃袋に入れ，12 月 30 日に橉場 に $0,0.5,1,2,3,5 \mathrm{~cm}$ の深さに埋めた。埋没後 1 カ月毎に掘出して発芽の有無および未発芽種子の発芽試 験をシャーレ上で行なつた。その結果を第 6 表に示す。

第 6 表 ヨモギ種子の越冬と発芽

\begin{tabular}{|c|c|c|c|c|c|c|c|}
\hline \multirow{2}{*}{$\begin{array}{c}\text { 埋 没 } \\
\text { 深 度 } \\
(\mathrm{cm})\end{array}$} & \multirow{2}{*}{ 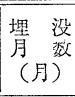 } & \multirow{2}{*}{$\begin{array}{c}\text { 俈 陚 } \\
\text { 種子数 } \\
\text { (粒) }\end{array}$} & \multirow{2}{*}{$\begin{array}{c}\text { 地 } \\
\text { 発芽数 } \\
\text { (粒) }\end{array}$} & \multirow{2}{*}{$\begin{array}{c}\text { 同 } \\
\text { 発芽率 } \\
(\%)\end{array}$} & \multicolumn{2}{|c|}{$\begin{array}{l}\text { 末 発 芽 種 } \\
\text { 子 } \\
\end{array}$} & \multirow{2}{*}{$\begin{array}{c}\text { 盒訫 } \\
\text { 発芽率 } \\
(\%)\end{array}$} \\
\hline & & & & & $\left|\begin{array}{l}\because+\frac{v}{2} \\
\text { 上発芽数 }\end{array}\right|$ & 枯死数 & \\
\hline \multirow{2}{*}{0.0} & 1 & 30 & 16 & 53.3 & 10 & 4 & 86.7 \\
\hline & 2 & " & 7 & 23.3 & 4 & 19 & 36.7 \\
\hline \multirow{2}{*}{0.5} & 1 & ") & 22 & 73.3 & 3 & 5 & 83.4 \\
\hline & 2 & ") & 17 & 56.7 & 1 & 12 & 60.0 \\
\hline \multirow{2}{*}{1.0} & 1 & I) & 12 & 40.0 & 9 & 9 & 70.0 \\
\hline & 2 & ") & 10 & 33.3 & 3 & 17 & 43.3 \\
\hline \multirow{2}{*}{ 2. 0} & 1 & ") & 14 & 46.7 & 3 & 13 & 56.7 \\
\hline & 2 & "I & 11 & 36.7 & 5 & 14 & 53.3 \\
\hline \multirow{2}{*}{3.0} & 1 & "I & 20 & 66.7 & 5 & 5 & 83.3 \\
\hline & 2 & " & 13 & 44.3 & 8 & 9 & 70.0 \\
\hline \multirow{2}{*}{5.0} & 1 & I & 16 & 53.3 & 6 & 8 & 73.3 \\
\hline & 2 & ") & 13 & 44.3 & 11 & 6 & 80.0 \\
\hline 室 内 & 1 & 100 & & & & 96.0 \\
\hline 则: 藏 & 2 & 100 & & & & & 97.0 \\
\hline
\end{tabular}

注）処理開始は 12 月 30 日

第 6 表より明らかなように, 土壤表層に放置した区 $(0$ $\mathrm{cm}$ ) では，1カ月後に約 50\% が発芳していたが，地中 に埋没した区でも各深度区ともに 40～70\% が地中で発 芽して抢り, 深度のちがいによつては発芽率に大きな差 は你かた。また深度 $5 \mathrm{~cm}$ の区でも約半数が発芽して いたが，この媣度はヨモギ種子の出芽限界（約 $3 \mathrm{~cm}$ ) 
以上の深度なので，この区で溌芽流てても地上には出 芽できず，地中で枯死するものと推定される。なおこれ らの処理に叔ける未発芽種子はシャーレ上の発芽試験 $\left(25^{\circ} \mathrm{C}\right)$ に㧍いて約 $20 \%$ が発芽した。また株の頭花内 で未発芽の状態で越冬した種子の発芽試験 $\left(23^{\circ} \mathrm{C}\right)$ を 1 月に行なつたところ，ほとんど発芽しなかつた。これ は，地上に落下せず頭花内で越冬した種子の大部分が成 熟不完全な種子だつたことによるのか，あるいはまた冬 季の低温により死滅したことによるのか，その原因につ いては不明である。

以上のことから，ヨモギ種子は稳実し落下すると，秋 から冬にかけての低温条件下にもかかわらず発芽し, 越 冬することが推察される。実際，自然条件下において も，12月 30 日，双葉の幼苗が開花結実した親株のまわ りの半径約 $50 \mathrm{~cm}$ 以内に多数観察された。その後観察を

続けたところによれば，1月下旬までは双葉が展開した ままのほとんど生長しない状態で越冬し，2 月初旬に本 葉は 1 枚， 3 月初旬には 4 枚，4 月初旬には 7 枚と気混 が上昇するにつれて急速に生長を始めた。

\section{2) 発芽と温度}

ヨモギは晚秋から初冬にかけての呧温下でもよく発芽 することから，次に種子の発芽と温度との関係について 調べた。発芽試験は直径 $7.5 \mathrm{~cm}$ のシャーレに十分水を 吸収させた沪紙を敷き,シャーレ当り 50 粒ずつ播種し て冷蔵庫および定温器内の暗黒下で行なつた。温度は, $0,5,10,15,20,25,30,33,35,40,45^{\circ} \mathrm{C}$ の 11 区 で，その各々は 2 区制とした。発芽調査は毎日 1 回定時 に明所で行なつた。なお比較のために明区と全暗黒下変 温区を設けた。明区はファイトトロンの自然光下，変温 区はファイトトロンの $25-20^{\circ} \mathrm{C}$ 変温室内であつた。そ 第 7 表 ヨモギ種子の発芽と温度

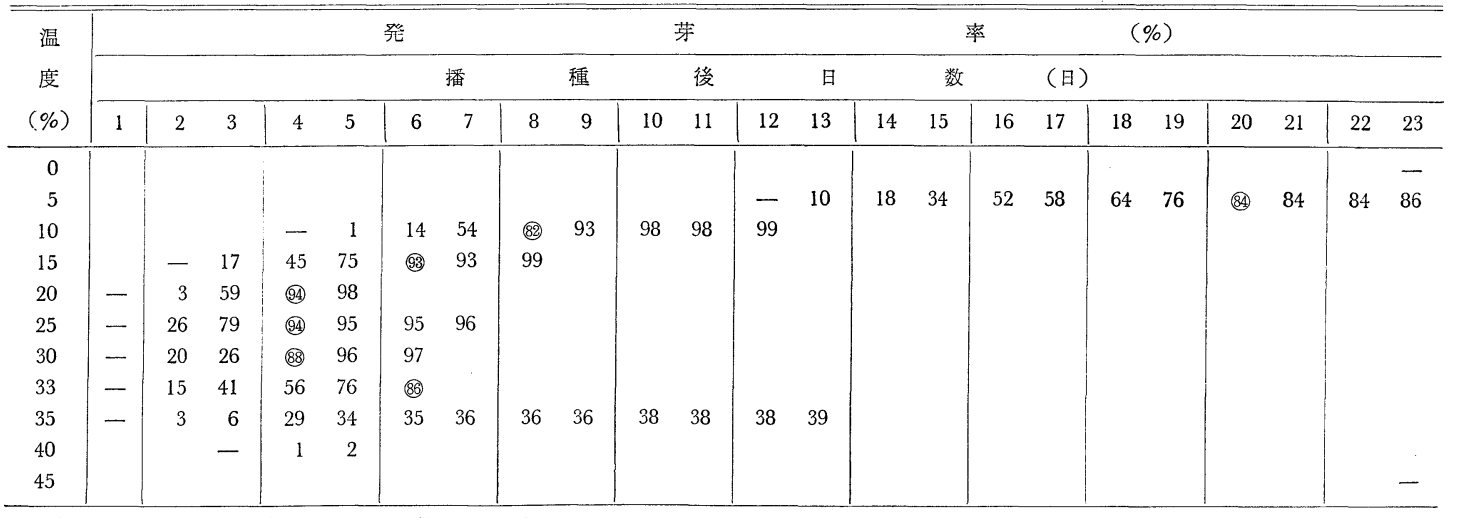

注）○印は発芽率が、80\%を越えた日数を示したもの。

の結果を第 7 表に示す。まず播種後発芽率が $80 \%$ をこ えるまでに要した日数についてみれば， $5{ }^{\circ} \mathrm{C}$ では 20 日

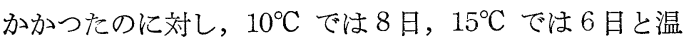

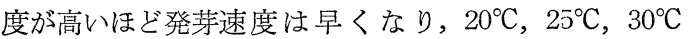
ではそれぞれ 4 日と最も短かかつた。ところが $33^{\circ} \mathrm{C} に$ なると発芽速度はやや抏そく，発芽率 $80 \%$ をこえるの

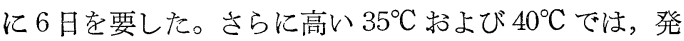
芽はみられたが，ともに発芽率は $40 \%$ 以下で，特に $40^{\circ} \mathrm{C}$ では $2 \%$ 発芽したのみであつた。一方 $45^{\circ} \mathrm{C}$ では 全く発芽せず, また $0^{\circ} \mathrm{C}$ では播種 1 力月後においても全 く発芽しなかつた。以上のことから，ヨモギ種子の最適 発芽温度は $20 \sim 30^{\circ} \mathrm{C}$, 最高発芽温度は $35 \sim 40^{\circ} \mathrm{C}$, 最低 発芽温度 $0 \sim 5^{\circ} \mathrm{C}$ と推定される。なお光の有無と発芽の 関係についてみれば，明区において $20^{\circ} \mathrm{C} ， 25^{\circ} \mathrm{C}$ および $25-20^{\circ} \mathrm{C}$ ともに発芽率は $90 \%$ 以上に達し, 全暗黒下変 温区においても明区と同様に高発芽率を示した。

3）土壌水分と発芽および出芽
雑草種子の発芽にとつても，一般に土㖶水分は最も不 可欠である。そこで次に, 土壌水分と発芽および出芽と の関係について実験を行なつた。土鎄水分は土䁃の絶乾 量に対し，5，10，15，20，25，30\% の6区を設けた。 なお供試土壌は砂質畑土壤で，土壤水分 $25 \%$ 区はほぼ 飽和状態であつた。さらに温度は，5，10，15，20， $25,30^{\circ} \mathrm{C}$ の 6 通りとし，播種深度は，0.5，1，2，3cm の4通りとした。容器には直径 $7.5 \mathrm{~cm}$ のシターレおよ び直径 $6 \mathrm{~cm}$ ，高さ $10 \mathrm{~cm}$ のガラス製ポットを用いた。 1 区 2 ポットとし，1ポット当り 25 粒播種した。覆土 後水分の蒸散を防ぐ目的でポットは透明ビニールで覆い をし, 冷蔵庫および定温器内に搬入した。その結果, 温 度のらがいによる発芽率, 出芽率の差はあまりに顕著で なかつたので，ここには比較的低温部の $15^{\circ} \mathrm{C}$ と高温部 の $25^{\circ} \mathrm{C}$ の結果を示す (第 8 表)。まず出芽に及ぼす温 度の高低についてみれば，覆土の厚さにかかわらず全般 に $15^{\circ} \mathrm{C}$ の方がよく, 特に覆土 $1 \mathrm{~cm}$ 区においてその傾 
第 8 表 土裹水分とヨモギ種子の出芽

\begin{tabular}{|c|c|c|c|c|c|c|c|c|c|c|c|c|c|}
\hline \multirow{3}{*}{$\begin{array}{l}\text { 温度 } \\
\left({ }^{\circ} \mathrm{C}\right)\end{array}$} & \multirow{3}{*}{$\begin{array}{l}\text { 覆土の } \\
\text { 厚 さ } \\
(\mathrm{cm})\end{array}$} & \multirow{3}{*}{$\begin{array}{l}\text { 土境 } \\
\text { 水分 } \\
(\%)\end{array}$} & \multicolumn{4}{|c|}{ 出 } & \multicolumn{2}{|l|}{ 芽 } & 率 & \multicolumn{2}{|c|}{$(\%)$} & & \\
\hline & & & \multicolumn{9}{|c|}{ 播 種 後 日 数 (日) } & & \\
\hline & & & 5 & 6 & 7 & 8 & 9 & 10 & 11 & 12 & 13 & 14 & 15 \\
\hline \multirow{10}{*}{15} & & 5 & & & & & & & & & & & - \\
\hline & & 10 & & - & 10 & 16 & 18 & 28 & 34 & & & & \\
\hline & 0.5 & 15 & & - & 12 & 18 & 24 & & & & & & \\
\hline & & 20 & & - & 10 & 12 & & & & & & & \\
\hline & & 25 & & & & - & 2 & & & & & & \\
\hline & & 5 & & & & & & & & & & & - \\
\hline & & 10 & & & & & - & 2 & 6 & 8 & 10 & & \\
\hline & 1.0 & 15 & & & & 一 & 6 & 14 & 16 & 20 & & & \\
\hline & & 20 & & & - & 14 & 14 & 24 & 26 & & & & \\
\hline & & 25 & & - & 2 & 6 & 6 & 6 & 8 & & & & \\
\hline \multirow{10}{*}{25} & & 5 & & & & & & & & & & & - \\
\hline & & 10 & - & 4 & & & & & & & & & \\
\hline & 0.5 & 15 & 8 & 8 & 10 & 10 & 14 & & & & & & \\
\hline & & 20 & 10 & 12 & 16 & I6 & 18 & & & & & & \\
\hline & & 25 & & & & & - & 4 & & & & & \\
\hline & & 5 & & & & & & & & & & & - \\
\hline & & 10 & - & 4 & & & & & & & & & \\
\hline & 1.0 & 15 & - & 8 & & & & & & & & & \\
\hline & & 20 & - & 2 & 2 & 2 & 2 & 2 & 4 & 4 & 4 & 6 & \\
\hline & & 25 & & & & & & & & & & & - \\
\hline
\end{tabular}

向が著しかつた。一方出芽に及ぼす覆土の厚さについて みれば， $15^{\circ} \mathrm{C}$ では覆土が $0.5 \mathrm{~cm}, 1 \mathrm{~cm}$ と少ない場合 は出芽率は約 30\% であつたが, 覆土の厚さが $2 \mathrm{~cm}$ ま たは $3 \mathrm{~cm}$ と厚い区では全く出芽はみられなかつた。一 方 $25^{\circ} \mathrm{C}$ 区では覆土 $0.5 \mathrm{~cm}$ にくらべ覆土 $1.0 \mathrm{~cm}$ 区で も非常に出芽率が低く，2cm区では土壌水分 $20 \%$ 区が わずか $4 \%$ 出芽したのみで, $3 \mathrm{~cm}$ 区では全然出芽しな かつた。次に, 土壤水分についてみ机，全般的に土壤 水分 $10 ， 15 ， 20 \%$ で出芽は良好であり，25\% 区は $15^{\circ} \mathrm{C}$ でわずかに出芽がみられたが， $25^{\circ} \mathrm{C}$ 区では $1 \mathrm{~cm}$ 覆土区でむ全く出芽しなかつた。また土壤水分 $5 \%$ 区で は全く出芽しなかつた。

\section{4) 水中発芽}

ヨモギは水分が飽和状態の土壤でもわずかながら発芽 したので, ニガヨモギの種子(6) と同様ヨモギ種子も水中 での発芽が可能ではないかと考えられたので，次のよう な実験を行なつた。 $500 \mathrm{cc}$ フラスコに劣沸水を入れ，種 子 10 粒をガーゼにつつみフラスコの底に沈め, コルク 栓をして $25^{\circ} \mathrm{C}$ および $10^{\circ} \mathrm{C}$ のファイトトロン自然光下に おいた。水深は約 $15 \mathrm{~cm}$ で, コルク栓と水面との間には 約 $1 \mathrm{~cm}$ の空間があつた。その結果は第 6 図に示す通り で，雨温度区とも50 90\% と水中でも良好な発芽がみ られた。なお $25^{\circ} \mathrm{C}$ では処理開始 2 週間後に発芽が始ま り，光をあててそのまま放置したところ最大 6 葉まで水 中で生育したが，その後は枯死した。

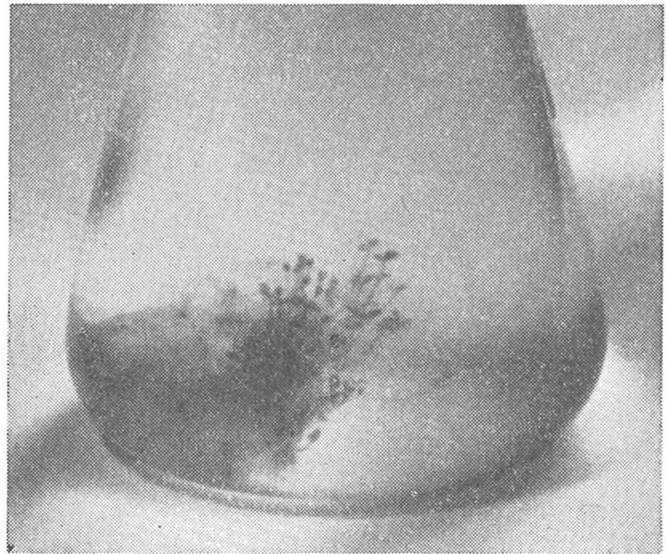

第 6 図 ヨモギ種子の水中発芼

煮沸水, $25^{\circ} \mathrm{C}$, 播理後約 1 力月

以上のようにヨモギ種子が水中発芽の能力をもつてい ることは、ヨモギの伝播を考える場合, 重視すべき点で はないかと思われる。

\section{5）土壌硬度と出芽}

自然条件下において種子の発芽を考える場合, 土壤水 分と同様に覆土の厚さおよび土壤硬度も重要な意義をも つている。そこで次に，覆土の厚さおよび硬度と出芽と の関係について調べた。直径 $9 \mathrm{~cm}$, 高さ $12 \mathrm{~cm}$ のブリ キ製ポットを用い, 1ポット当り 10 粒播種した。土袞 硬度は $0.1 \mathrm{~kg} / \mathrm{cm}^{3}$ と $0.2 \mathrm{~kg} / \mathrm{cm}^{3}$ (山中式硬度計測 定）, 覆士の厚さは $0.5 \mathrm{~cm}$ と $1 \mathrm{~cm}$ で 1 区 2 ポットと し，温度はファイトトロンの $25-20^{\circ} \mathrm{C}$ であつた。なお 供試土壤は水分含量 $12.1 \%$ (絶乾比) 亿調整した砂質 畑土壤であつた。その結果を第 9 表に示す。

筙 9 表 土壤硬度と種子の出芽

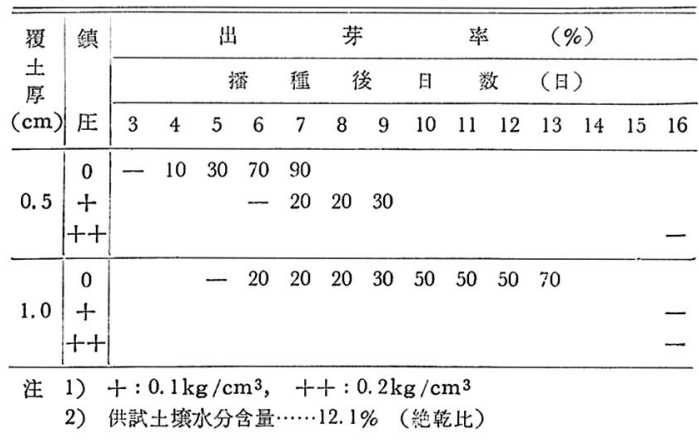

第 9 表より，無鎮圧区の出芽率は覆土の厚さ $0.5 \mathrm{~cm}$ 区で $90 \% ， 1 \mathrm{~cm}$ 区で $70 \%$ であったのに対し，硬度 $0.1 \mathrm{~kg} / \mathrm{cm}^{3}$ 区では覆土 $0.5 \mathrm{~cm}$ 区で $30 \%$ が出芽した が $1 \mathrm{~cm}$ 区では全然出芽できず, 硬度 $0.2 \mathrm{~kg} / \mathrm{cm}^{3}$ 区で は覆土 $0.5 \mathrm{~cm}$ 区, $1 \mathrm{~cm}$ 区ともに全く出芽できなかつ 
た。なお全く出芽できなかつたこれらの硬度区において は，大半池中で発芽していたが，覆土が硬いため途中 で伸びが停止していた。

\section{摘要}

（1） ヨモギは短日植物であり，全日長下では花をつ けなかつた。

（2） 1 株内の開花順序は，主荎の中央部の第 1 次分 枝の基部および中央部に㧊いて最も早く次第に周辺に及 び，主茎の頂端部は最もおそかつた。なお北部九州にお ける出蕾期は 8 月下旬 9 月上旬, 開花期は 9 月下旬 10 月上旬であつた。

（3） ヨモギ1株当りの頭花数は 2 千〜 1 万 4 千で， 1 頭花内には約 15 17 個の小花があつた。なお 1 頭花 内の舌状花および筒状花の割合は $4: 6$ ないし $5: 5$ で あつた。

（4） 1 株当りの稔実率は 2 40\% であつたが，平均 すると約 $20 \%$ であつた。このことから 1 株当りの稔実 粒数は 5 千〜 4 万粒と考えられる。

（5）開花後種子が発芽能力を持つようになるまでの 日数は約 20 日で，50日経過すると発芽能力はほぼ最高 となつた。また約 70 日経過すると目然落果が始まつ た。

（6）ヨモギ種子には休眠はなく, 越冬は一般に双葉 の幼苗の形で行なわれるようであつた。

(7) ヨモギ種子の最適発芽温度は $20 \sim 30^{\circ} \mathrm{C}$, 最高
発芽温度は $35 \sim 40^{\circ} \mathrm{C}$, 最低発芽温度は $0 \sim 5^{\circ} \mathrm{C}$ 上推定 される。なお光の有無および变温は発芽に影響がなかつ た。

（8）出芽は土壤水分 10 20\%（絶乾比）で良好で あり，温度については比較的低温において高温より良好 であつた。また水分飽和状態の土壤でもわずかながら出 芽した。

（9）ヨモギは煮沸水中でも発芽し，最大 6 葉ぐらい まで生長を続けた。

(10) 土袞硬度 $0.1 \mathrm{~kg} / \mathrm{cm}^{3}$ では覆土の厚さ $0.5 \mathrm{~cm}$ 区で播種種子の $30 \%$ が出芽したが，1 cm 区では全く 出茅しなかつた。また $0.2 \mathrm{~kg} / \mathrm{cm}^{3}$ では覆土 $0.5 \mathrm{~cm}$ ， $1 \mathrm{~cm}$ 区ともに全く出芽しなかつた。

（11）播種後 60 日目の実生苗の茎の基部に培土した ところ，茎基部の腋芽が新地下茎に変化することがわか つた。

\section{文献}

1）赤座光市：農地雑草の早産性及び多産性. 農及園 15 (1)，161〜 162 (1940).

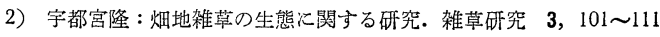
(1964).

3) 笠原安夫 : 雑草の特改と雑草害. 作物大系 14, 13 (1962).

4）北村四郎：原色日本植物図鑑 上. (1965).

5）クーグレル（中野治房訳）: 花生態学, 222. 広川書店, 東京. (1966).

6) 盛永俊太郎 : Ameri. Jour. Bot. 13, (1926). 1

7）伊藤健次・井之上䍃：井手敛也： ヨモギの生理生態拉よびその防 除法䍩する研究 (第1 報). 雑草研究 5, 85 90 (1966).

\section{Physiological and Ecological Studies on Artemisia princeps Pamp.}

\section{Seed Propagation}

Kenji Ito, Kinya Ide, and Jun Inouye

Faculty of Agriculture, Kyushu University, Fukuoka

\section{Summary}

1) In southern part of Japan, the time of flowering of Artemisia princeps Pamp. is late september to early october. As the results of experiments the flowering was observed under short day ( 8 hours light), and did not under long day condition (continuous light).

2) Number of head per plant was $2,000 \sim 14,000$, and a head consisted of about $15 \sim 17$ florets. On the other hand, the rate of fructification of the florets was about $2 \sim 40$ per cent, averaged about 20 . per cent. From the results, number of seeds per plant was about 5,000 40,000.

3) About 20 days after flowering, the seeds had an ability of germination, and it reached maximum. after about 50 days. This result showed that the seeds had no dormancy. From our observations, it seemed that the seeds germinate from late autumn to early winter and pass through winter season with cotyledonary plants. 
4) Effect of temperature on germination of the seeds was as follows : minimum temperature ; $0 \sim 5^{\circ} \mathrm{C}$, optimum temperature; $20 \sim 30^{\circ} \mathrm{C}$, maximum temperature ; $35 \sim 40^{\circ} \mathrm{C}$.

5) The rate of emergence of cotyledonary plants war good under the soil of $10 \sim 20$ per cent soil moisture content, and it decreased with the increase of soil moisture content. However, the seeds were able to germinate in boiled water, and it grown up to 6 leaf stage under the water.

6) The rate of emergence was also affected by the depth of seeding, and it decreased with the increase of the depth of seeding. As the effect of soil compaction of cover soil after seeding, in the plot of $0.1 \mathrm{~kg} / \mathrm{cm}^{3}$-compaction 30 per cent of seeds emerged at $0.5 \mathrm{~cm}$-seeding depth and did not emerge at $1.0 \mathrm{~cm}$-seeding depth. In the plot of $0.2 \mathrm{~kg} / \mathrm{cm}^{3}$-compaction no emergence occured even at the plot of $0.5 \mathrm{~cm}$-seeding depth.

\title{
ミズガヤツリとクログワイに対する数種除草剤の雑草処理 における殺草性について
}

\author{
農林省農事試験場 中川恭二郎・宮原益次
}

\section{1. まえがき}

水田雑草ミズガヤツリ（Cyperus serotinus Rottb.） は最近水稲の早期栽培や直播栽培で目立つようになつて きた。その防除法としては稲刈取後に 2,4-D や 2,4-D・ ATA を散布するのが有効であることが知られてい $る^{1,2)}$ 。しかしその効果が大きいのは早期栽培の稲刈取 後だけであり，処理時期がおそくなると効果が著しく低 下する。クログワイ (Eleocharis tuberosa Shult. var. Kuroguwai Makino) もミズガヤツリと同じくカヤツ リグサ科であるが，除草剤による防除法は未だ明らかに されていない。

多年生雑草に対しては除草剂の效力が地下茥にまで及 ぶものでないと永続的な効果は期待できない。ミズガヤ ツリ，クログワイともに 9 月はじめ頃から地下に塊茎な ど越冬器官を形成するので，処理時期によつては除草剤 の效果が大きく変動するのではないかと考えた。そこで 生育の比較的早い時期から塊茎形成期までの閒，4回に わたつて除草剤を処理し, 地上部および越冬用の地下器 官に及ぼす除草剤の影響の処理時期による差異を明らか にしようとした。稲刈取後処理の効果の変動の原因を検 討すると同時に生育期処理の手がかりを得ようとしたも のである。

これまでの試験によつて多年生雑草に有効とみられて いる移行型除草剤 MCP, ATA, MCP+ATA, para-
quat，DPA の 5 種類について試験を行なつた。

\section{2. 試 験 方 法}

$90 \mathrm{~cm}$ 角のコンクリートポットで増殖させたミズガヤ ツリとクログワイの苗を 2 千分の 1 a の合成樹脂製ポッ トに，1ポット当たり 3 本つっ， 7 月 10 日に植付け た。

植付後 9 月中旬までは水深約 $3 \mathrm{~cm}$ の湛水とし, 以後 は落水して屋外に置いた。湛水期間中に除草剤を処理す るときは，前日に地表水を排除した。

除草剤散布には小型コンプレッサーを用い, 吐出圧力 を $0.75 \sim 1.00 \mathrm{~kg} / \mathrm{cm}^{2}$ とし, 展着剂を $0.02 \%$ 加用し て散布した。散布後 3 日間は降雨時だけビニールシート で覆つて，除草剂が茎葉から流亡するのを防止した。

供試除草剤の種類と使用量は第 1 表の通りである。本 試験は雑草に対する除草剤の影響を明らかにすることに 重点をおいたので, 水稲に対する薬害は考慮していない。 第 1 表 供試除草剤の種類と使用量

\begin{tabular}{|c|c|c|}
\hline 種 & 剤型および含有有効成分量 & $\begin{array}{c}\text { 使 } \text { 用 }^{\text {量* }} \\
\text { (有効成分量 } \mathrm{g} / \mathrm{a} \text { ) }\end{array}$ \\
\hline MC P（ナトリウム塩） & 液 剂 $20 \%$ (酸として) & 20 , \\
\hline A T A (amitrole) & 水溶剂 $90 \%$ & 20 , \\
\hline $\mathrm{MCP}+\mathrm{ATA}$ & 上記 2 薬剤を散布前に混合 & $10+10,20+20$ \\
\hline paraquat (ジクロライド) & 夜 戍 $20 \%$ (イオンとし & 4, \\
\hline D P A (dalapon) & 水溶剂 $85 \%$ & 100 \\
\hline
\end{tabular}

注）＊月18日までの処理では使用量は 2 段階であつたが，9月15日 以後の迈理では多量だけの1段階とした。 